\title{
Feasibility of coal fly ash based bricks and roof tiles as construction materials: a review
}

\author{
M.N. Akhtar ${ }^{1 *} O$. Hattamleh$^{2}$ and J.N. Akhtar ${ }^{3}$ \\ ${ }^{1}$ Department of Civil Engineering Fahad Bin Sultan University, Tabuk, Saudi Arabia \\ 2 Department of Civil Engineering Hashemite University, Zarqa 13133, Jordan \\ 3University Polytechnic Civil Engineering section, A.M.U Aligarh
}

\begin{abstract}
The aim of present study is to investigate about the potential use of coal fly ash along with other natural and solid wastes for the production of coal fly ash based bricks and roof tiles. The study is based on the comprehensive reviews available from the previous experimental data on coal fly ash based bricks and roof tiles. The study intendeds to provide the essential technical information and data for the use of fly ash mix with other solid wastes and reveal their suitability as construction materials. It has been found that samples were non-hazardous in nature and vigorously used as an additional construction materials and their compositions are perfectly fit to make the strong composite material for bricks and tiles. The three past studies have been demonstrated that, fly ash based bricks and roof tiles provides a sustainable supplement to the traditional clay bricks and roof tiles, that not only increases the efficiency of traditional bricks and roof tiles but also helps significantly to reduce the environmental issues associated with the disposal of these waste materials. In addition to this study highlights the potential use of fly ash for producing sustainable construction materials.
\end{abstract}

\section{Introduction}

Fly ash (F.A) particles typically solidify while they are still in suspension in exhaust gases and thus are generally spherical in shape. F.A is composed primarily of silica $\left(\mathrm{SiO}_{2}\right)$, alumina $\left(\mathrm{Al}_{2} \mathrm{O}_{3}\right)$, and iron oxide $\left(\mathrm{Fe}_{2} \mathrm{O}_{3}\right)$. Physical and chemical requirements for F.A usually vary depending on its intended use. Accordingly, specific requirements for use of F.A in concrete or soil stabilization are described in [1]. Standard specification for coal F.A and Raw or Calcined Natural Pozzolan for use in Concrete and [2], standard specification for F.A and other Pozzolans use with Lime for Soil stabilization, respectively. The plasticity index of mixture of fly ash and clay decreases on drastically with increase of replacing ratio of F.A was to be determined [3]. The traditional construction materials such as concrete, bricks, hollow blocks, solid blocks, pavement blocks and tiles are being produced from the existing natural resources. This damages the environment due to continuous exploration and depletion of natural resources. Moreover, various toxic substances such as high concentration of carbon monoxide, oxides of sulfur, oxides of nitrogen, and suspended particulate matters are invariably emitted to the atmosphere during the manufacturing process of construction materials. The emission of toxic matters contaminates air, water, soil, flora, fauna and aquatic life, and thus influences human health as well as their living standards. Therefore, the issues related to environmental conservation have gained great importance in our society in recent years [4]. Municipal solid waste incineration (MSWI) ash is used in part as raw materials for cement clinker production by taking advantage of the high contents of $\mathrm{SiO}_{2}, \mathrm{Al}_{2} \mathrm{O}_{3}$, and $\mathrm{CaO}$. It is necessary for environmental reasons to establish a material utilization system for the incineration waste ash residue instead of disposing these ashes into landfill [5]. The utilization of solid wastes in construction materials is one of such

* Corresponding author : nakhtar@fbsu.edu.sa 
innovative efforts. The cost of construction materials is increasing day by day because of high demand, scarcity of raw materials, and high price of energy. From the standpoint of energy saving and conservation of natural resources, the use of alternative constituents in construction materials is now a global concern.

For this, the extensive research and development works towards exploring new ingredients are required for producing sustainable and environment friendly construction materials. The present study investigates about the potential use of fly ash based bricks and tiles as construction material resulting in either full or partial replacement of clay bricks and tiles.

\section{Chemical analysis of F.A and R.S.D}

The procedures used in the chemical analysis of fly ash to determine the oxides of silica, aluminum, iron, calcium, magnesium, total sodium and total potassium is as follows heat the sample prior to fusing as indicated for material previously ashed in ASTM Designation: D 4326. Weigh $0.50 \mathrm{~g}$ of the ashed fly ash sample and $6.5 \mathrm{~g}$ of fluxing material into the crucible. Add $400 \mu \mathrm{L}$ of liquid lithium bromide to the sample before fusing. Determine loss on ignition, available sodium oxide, available potassium oxide and available alkali in accordance with ASTM Designation: C 311. 3. Determine sulfur trioxide with the carbon sulfur determinator. The apparatus used in the study are XRF (X-ray Fluorescence) X-ray diffraction (XRD), and wavelength dispersive spectroscopy (microprobe WDS). X-ray microanalysis (EDS) techniques are being used in the chemical analysis of fly ash (F.A) and radish stone dust (R.S.D). In the construction industry, the combination of SEM and EDS are being used particularly for quality control and verification of material composition. The VEGA3 SEM, which is fully compatible with any EDS system, is a powerful tool for quality control and development in the construction industry. Locally available T.F.A and R.S.D samples were examined in the present study. After examination of the samples it has been found that both samples were nonhazardous in nature and vigorously used as an additional construction materials. EDS analysis was performed using Bruker's Quantax system to determine the chemical composition of the T.F.A and R.S.D particles. The chemical composition of T.F.A and R.S.D particles and the element distribution over the sample surface was determined by EDS. Exact chemical composition is then summarized in Table 1 and 2.

Table 1. List of Elements and Concentrations of T.F.A.

\begin{tabular}{|l|l|l|}
\hline Element & \multicolumn{1}{|c|}{ Weight $\%$} & Atomic\% \\
\hline $\mathrm{C}$ & 14.42 & 21.05 \\
\hline $\mathrm{O}$ & 54.59 & 59.83 \\
\hline $\mathrm{Al}$ & 11.96 & 7.77 \\
\hline $\mathrm{Si}$ & 16.47 & 10.29 \\
\hline $\mathrm{K}$ & 0.73 & 0.33 \\
\hline $\mathrm{Ca}$ & 0.94 & 0.41 \\
\hline Ti & 0.88 & 0.32 \\
\hline Totals & 100.00 & \\
\hline
\end{tabular}


Table 2. List of Elements and Concentrations of R.S.D.

\begin{tabular}{|l|l|l|}
\hline Element & \multicolumn{1}{|c|}{ Weight $\%$} & Atomic\% \\
\hline $\mathrm{O}$ & 59.96 & 75.21 \\
\hline $\mathrm{Al}$ & 11.11 & 8.26 \\
\hline $\mathrm{Si}$ & 19.53 & 13.95 \\
\hline $\mathrm{K}$ & 2.17 & 1.11 \\
\hline $\mathrm{Fe}$ & 2.81 & 1.01 \\
\hline $\mathrm{Au}$ & 4.42 & 0.45 \\
\hline Totals & 100.00 & \\
\hline
\end{tabular}

Apart from oxygen, silicon and aluminum, from which the fly ash is usually composed; many other elements were found as well. In R.S.D samples iron and many other elements were also found with the combination of oxygen, silicon and aluminium. The presence of diverse elements in fly ash particles might be attributed to the type of coal being used. The Quantitative results from point analysis of T.F.A and R.S.D are being used in the study are also shown in Figure.1 and Figure.2.

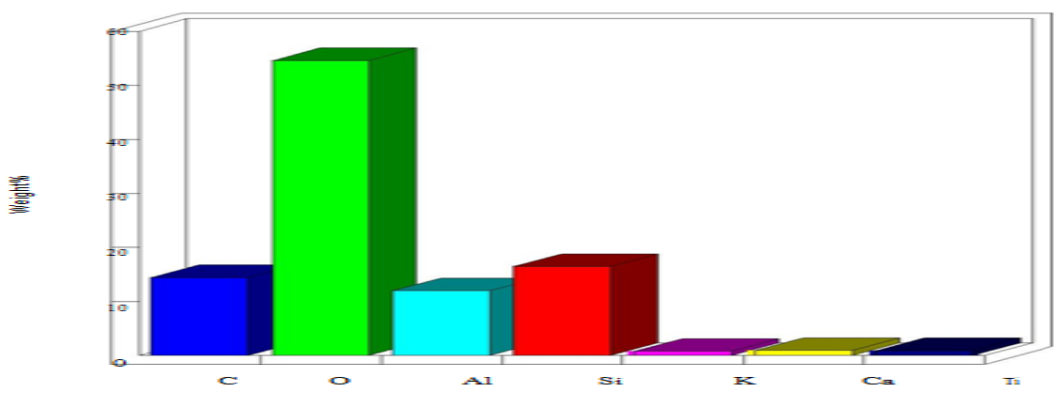

Fig. 1. Quantitative results from point analysis of TFA.

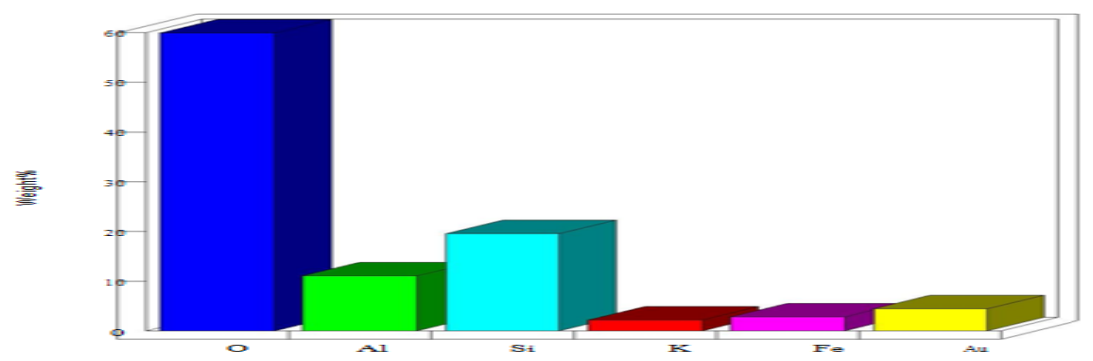

Fig. 2. Quantitative results from point analysis of RSD.

The fly ash consists of fine powdery particles that are predominantly spherical in shape, either solid or hollow and mostly glassy in nature. The particles size distribution of most bituminous coal fly ashes is generally similar to that of silt $(<0.075 \mathrm{~mm})$. Although, Sub-bituminous coal fly ashes or class C fly ash is generally slightly coarser than bituminous coal ranges between $0.002 \mathrm{~mm}-0.1 \mathrm{~mm}$. Figure. 3 shows the variation of particles in XRF, T.F.A at 3000x Magnification and Fig. 4 shows SE image of T.F.A at $6000 \mathrm{x}$ Magnification were collected from Harduaganj Thermal Power Station U.P (India). 


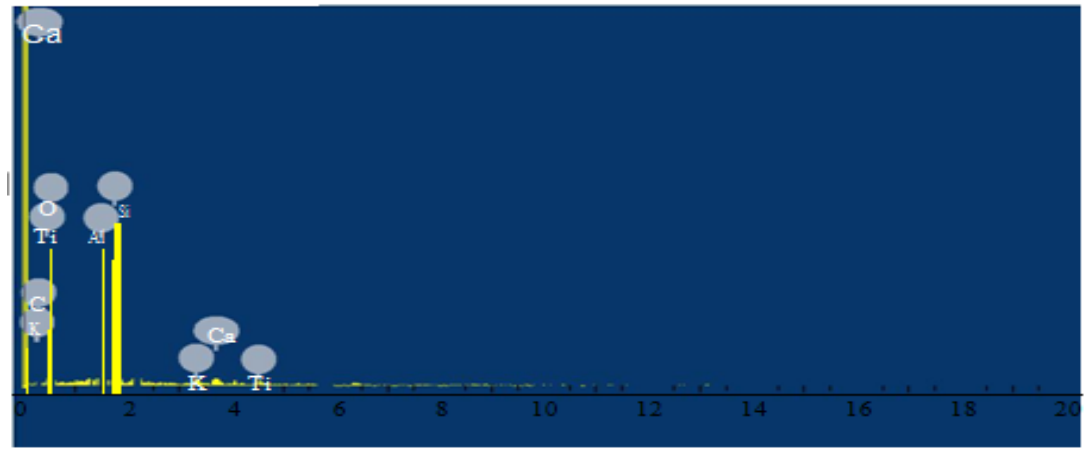

Fig. 3. Spectrum from point analysis of TFA particles at 3000x.

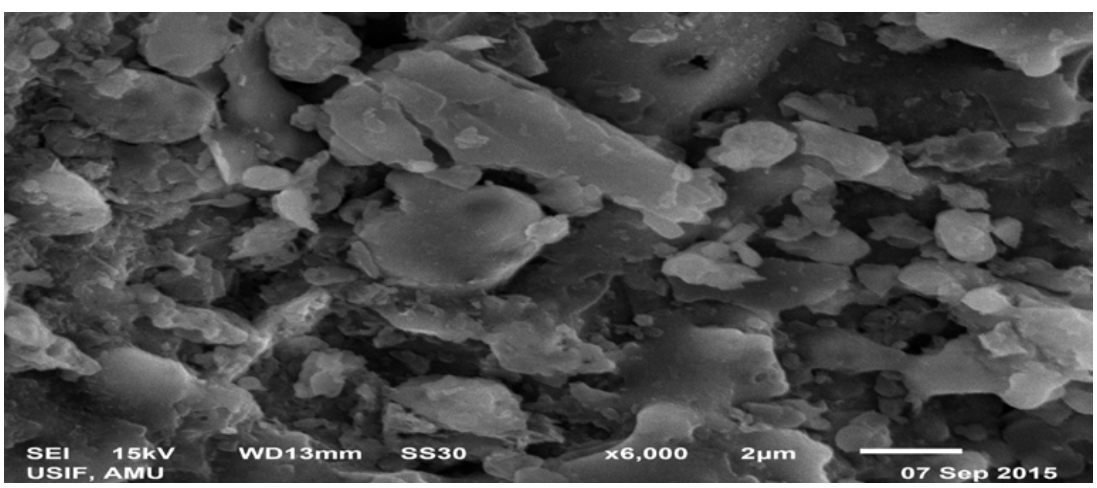

Fig. 4. SE image of TFA at $6000 \mathrm{x}$.

Construction material such as Radish Stone Dust (R.S.D) admixtures are mixed with cement particles and improved the particle packing of cement paste, thus reducing permeability (k). Figure. 5 and 6 shows the XRF, R.S.D particles at $3000 \mathrm{x}$ magnification and SE image of R.S.D at 6000x magnification was collected locally.

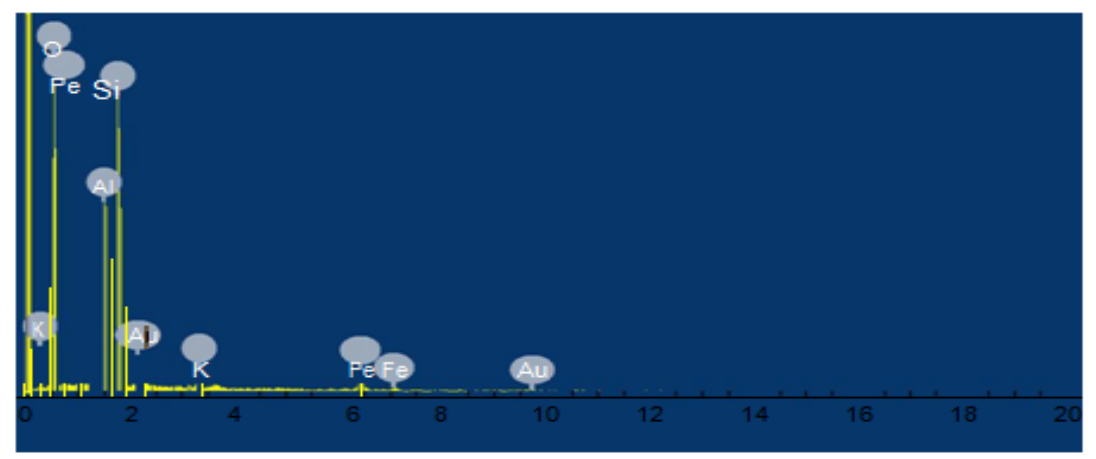

Fig. 5. Spectrum from point analysis of RSD particles at 3000x 


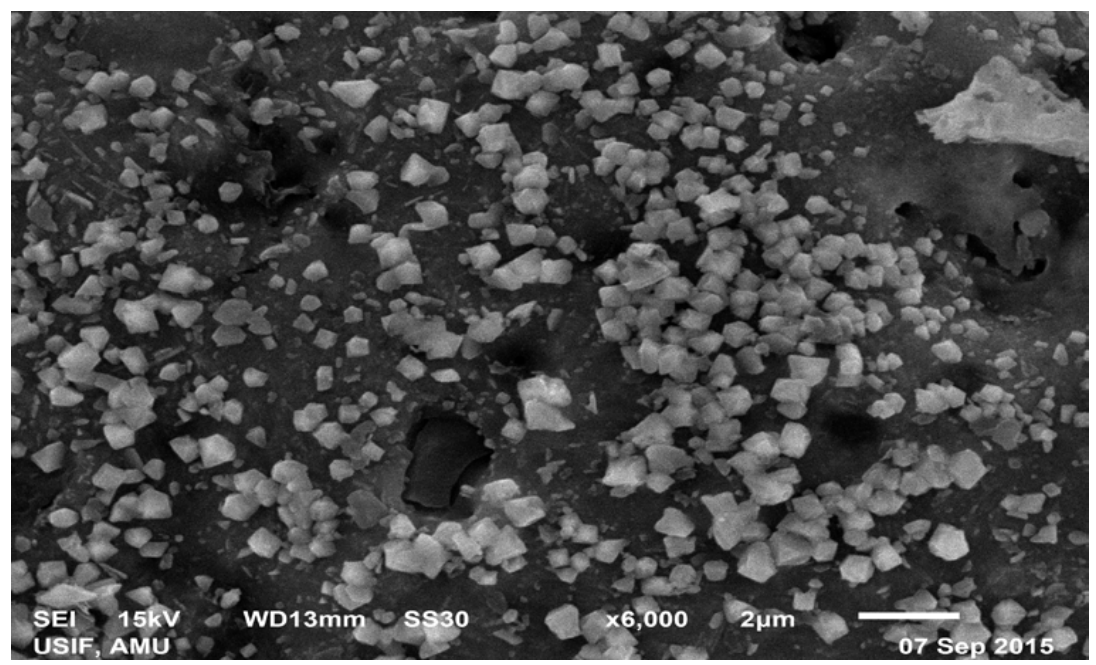

Fig. 6. SE image of RSD $6000 x$

\section{Comparison of past experimental results}

Only few studies have been conducted on fly ash based bricks and tiles. Since fly ash based bricks and tiles is an assemblage of fly ash and other materials. The comprasion is based on three recent past stidies. It is generally believed that the strength and durability of fly ash based bricks and tiles would lie somewhere between that of bond of fly ash and other mixed materials. It may be true in cases when one combination of mould, i.e., cement, fly ash, sand and stone dust, etc is substantially weaker and softer than other, for example variation of these materials play a significant role to change their strength as reported by [6]. Series of tests were conducted on different combinations with partial replacement of clay for making fly ash bricks and it was observed that the combination of materials play a significant role to change the compressive strength. The combination of fibre reinforced fly ash lime stone dust brick (25FRFALSDB9') was found to have highest compressive strength $(9.155 \mathrm{MPa})$ with $50 \%$ Treated fly ash combination at $10 \%$ cement. It was found that when the amount of treated fly ash changes with respect to the stone dust and sand replacement, the compressive strength increased and was found to be maximum $25 \%$ stone dust-sand combination with $50 \%$ treated fly ash. The variation of strength is shown in Figure. 7(a). Based on experimental data [7] series of tests were conducted on fly ash based brick tiles. It was observed that the compressive strength of these tiles increases with increase in bond strength of the composite material along with other factors. It has been also observed that the permeability reached at lower value at the same whereas compressive strength was reached at maximum. After experimental investigation it has been carried out that the tiles were failed on lower compressive strength as compare to the conventional clay brick tiles. The variation of compressive strength is shown in Figure. 7(b). The highest compressive strength reached $(6.896 \mathrm{MPa})$ for the combination of 15 TFASDBT. In other study was carried out on fly ash based roof tiles with waste polythene fibres [8]. The compressive strength has been increased by $30.65 \%$ compared to the past study carried out by [7]. The studied compressive strength behavior has been shown in Figure. 7(c) and (d). The detailed experimental data of the past investigations are given in Table 3 , shows the compressive strength behavior of the studies. 
Table 3. Comparison of Past Experimental Results of Fly ash Based Bricks and Roof Tiles.

\begin{tabular}{|c|c|c|c|c|c|c|c|c|c|}
\hline \multicolumn{3}{|c|}{ J.Alam et al. (2013) } & \multicolumn{3}{|c|}{ J.N Akhtar et al. (2010) } & \multicolumn{4}{|c|}{ Akhtar M.A et al. (2016) } \\
\hline $\begin{array}{c}\text { Mould } \\
\text { Designations }\end{array}$ & $\begin{array}{l}\text { Compressi } \\
\text { ve Strength } \\
\text { (MPA) }\end{array}$ & $\begin{array}{c}\text { Mould } \\
\text { Designations }\end{array}$ & $\begin{array}{l}\text { Compressive } \\
\text { Strength } \\
\text { (MPA) }\end{array}$ & $\begin{array}{l}\text { Mould } \\
\text { Desig- } \\
\text { ations }\end{array}$ & $\begin{array}{l}\text { Compress-ve } \\
\text { Strength } \\
\text { (MPA) }\end{array}$ & $\begin{array}{l}\text { Mould } \\
\text { Designati } \\
\text { ons }\end{array}$ & $\begin{array}{l}\text { Compr- } \\
\text { ssive } \\
\text { Strength } \\
\text { (MPA) }\end{array}$ & $\begin{array}{l}\text { Mould } \\
\text { Designat- } \\
\text { ons }\end{array}$ & $\begin{array}{c}\text { Compressi } \\
\text { ve } \\
\text { Strength } \\
\text { (MPA) }\end{array}$ \\
\hline 00FABT & 3.636 & $00 \mathrm{FAB}$ & 3.348 & $\begin{array}{c}\text { 00FALSD } \\
\text { B1 }\end{array}$ & 3.666 & $\begin{array}{c}00 \\
\text { TFASDRT } \\
70\end{array}$ & 3.56 & $\begin{array}{c}\text { 10TFASDR } \\
\text { T15 }\end{array}$ & 6.04 \\
\hline 05FABT & 3.688 & $05 \mathrm{FAB}$ & 3.69 & $\begin{array}{c}\text { 05FALSD } \\
\text { B2 }\end{array}$ & 4.235 & $\begin{array}{c}05 \\
\text { TFASDRT } \\
70\end{array}$ & 3.84 & $\begin{array}{l}\text { 15TFASDR } \\
\text { T15 }\end{array}$ & 6.54 \\
\hline 10FABT & 3.755 & $10 \mathrm{FAB}$ & 4.39 & $\begin{array}{c}\text { 10FALSD } \\
\text { B3 }\end{array}$ & 7.156 & $\begin{array}{c}10 \\
\text { TFASDRT } \\
70\end{array}$ & 4.25 & $\begin{array}{l}\text { 20TFASDR } \\
\text { T15 }\end{array}$ & 6.98 \\
\hline $15 \mathrm{FABT}$ & 3.94 & $15 \mathrm{FAB}$ & 5.385 & $\begin{array}{c}\text { 15FALSD } \\
\text { B4 }\end{array}$ & 6.569 & $\begin{array}{c}15 \\
\text { TFASDRT } \\
70\end{array}$ & 4.19 & $\begin{array}{c}\text { 25TFASDR } \\
\text { T15 }\end{array}$ & 6.35 \\
\hline 20FABT & 3.69 & $20 \mathrm{FAB}$ & 4.45 & $\begin{array}{c}\text { 20FALSD } \\
\text { B5 }\end{array}$ & 4.79 & $\begin{array}{c}20 \\
\text { TFASDRT } \\
70\end{array}$ & 3.89 & $\begin{array}{l}\text { 30TFASDR } \\
\text { T15 }\end{array}$ & 6.3 \\
\hline 00TFABT & 4.055 & 00FRFAB & 3.748 & $\begin{array}{l}\text { 00FRFAL } \\
\text { SDB1' }\end{array}$ & 3.666 & $\begin{array}{c}00 \\
\text { TFASDRT } \\
60\end{array}$ & 3.74 & $\begin{array}{l}\text { 10TFASDR } \\
\text { T20 }\end{array}$ & 8.52 \\
\hline 05TFABT & 4.1 & 05FRFAB & 3.99 & $\begin{array}{l}\text { 05FRFAL } \\
\text { SDB2' }\end{array}$ & 4.235 & $\begin{array}{c}05 \\
\text { TFASDRT } \\
60\end{array}$ & 4.06 & $\begin{array}{c}\text { 15TFASDR } \\
\text { T20 }\end{array}$ & 8.75 \\
\hline 10TFABT & 4.31 & 10FRFAB & 4.79 & $\begin{array}{l}\text { 10FRFAL } \\
\text { SDB3' }\end{array}$ & 8.156 & $\begin{array}{c}10 \\
\text { TFASDRT } \\
60\end{array}$ & 4.47 & $\begin{array}{l}\text { 20TFASDR } \\
\text { T20 }\end{array}$ & 9.01 \\
\hline $15 \mathrm{TFABT}$ & 4.535 & 15FRFAB & 6.35 & $\begin{array}{l}\text { 15FRFAL } \\
\text { SDB4' }\end{array}$ & 6.569 & $\begin{array}{c}15 \\
\text { TFASDRT } \\
60\end{array}$ & 4.35 & $\begin{array}{l}\text { 25TFASDR } \\
\text { T20 }\end{array}$ & 8.95 \\
\hline 20TFABT & 4.315 & 20FRFAB & 4.75 & $\begin{array}{l}\text { 20FRFAL } \\
\text { SDB5' }\end{array}$ & 4.79 & $\begin{array}{c}20 \\
\text { TFASDRT } \\
60\end{array}$ & 4.15 & $\begin{array}{l}\text { 30TFASDR } \\
\text { T20 }\end{array}$ & 7.99 \\
\hline 00TFASDBT & 4.845 & 00FALB & 3.685 & $\begin{array}{c}\text { 10FALSD } \\
\text { B6 }\end{array}$ & 8.16 & $\begin{array}{c}00 \\
\text { TFASDRT } \\
50\end{array}$ & 4.05 & & \\
\hline 05TFASDBT & 5.3 & 05FALB & 4.065 & $\begin{array}{c}\text { 15FALSD } \\
\text { B7 }\end{array}$ & 8.33 & $\begin{array}{c}05 \\
\text { TFASDRT } \\
50\end{array}$ & 4.35 & & \\
\hline 10TFASDBT & 5.48 & 10FALB & 4.865 & $\begin{array}{c}\text { 20FALSD } \\
\text { B8 }\end{array}$ & 8.520 & $\begin{array}{c}10 \\
\text { TFASDRT } \\
50\end{array}$ & 4.61 & & \\
\hline 15TFASDBT & 5.9 & 15FALB & 6.599 & $\begin{array}{c}\text { 25FALSD } \\
\text { B9 }\end{array}$ & 8.890 & $\begin{array}{c}15 \\
\text { TFASDRT } \\
50\end{array}$ & 4.53 & & \\
\hline 20TFASDBT & 5.714 & 20FALB & 4.596 & $\begin{array}{l}\text { 30FALSD } \\
\text { B10 }\end{array}$ & 7.480 & $\begin{array}{c}20 \\
\text { TFASDRT } \\
50\end{array}$ & 4.41 & & \\
\hline 10TFASDBT & 4.69 & 00FRFALB & 4.185 & $\begin{array}{c}\text { 10FRFAL } \\
\text { SDB6' }\end{array}$ & 8.315 & $\begin{array}{c}10 \\
\text { TFASDRT } \\
10\end{array}$ & 4.61 & & \\
\hline 15TFASDBT & 6.896 & 05FRFLAB & 5.465 & $\begin{array}{l}\text { 15FRFAL } \\
\text { SDB7' }\end{array}$ & 8.545 & $\begin{array}{c}15 \\
\text { TFASDRT } \\
10\end{array}$ & 4.53 & & \\
\hline 20TFASDBT & 6.24 & 10FRFALB & 5.85 & $\begin{array}{l}\text { 20FRFAL } \\
\text { SDB8 }\end{array}$ & 8.625 & $\begin{array}{c}20 \\
\text { TFASDRT } \\
10\end{array}$ & 4.41 & & \\
\hline 25TFASDBT & 5.77 & 15FRFALB & 7.859 & $\begin{array}{l}\text { 25FRFAL } \\
\text { SDB9' }\end{array}$ & 9.155 & $\begin{array}{c}25 \\
\text { TFASDRT } \\
10\end{array}$ & 4.38 & & \\
\hline 30TFASDBT & 5.39 & 20FRFALB & 5.46 & $\begin{array}{l}\text { 30FRFALS } \\
\text { DB10' }\end{array}$ & 7.755 & $\begin{array}{c}30 \\
\text { TFASDRT } \\
10\end{array}$ & 4.25 & & \\
\hline
\end{tabular}



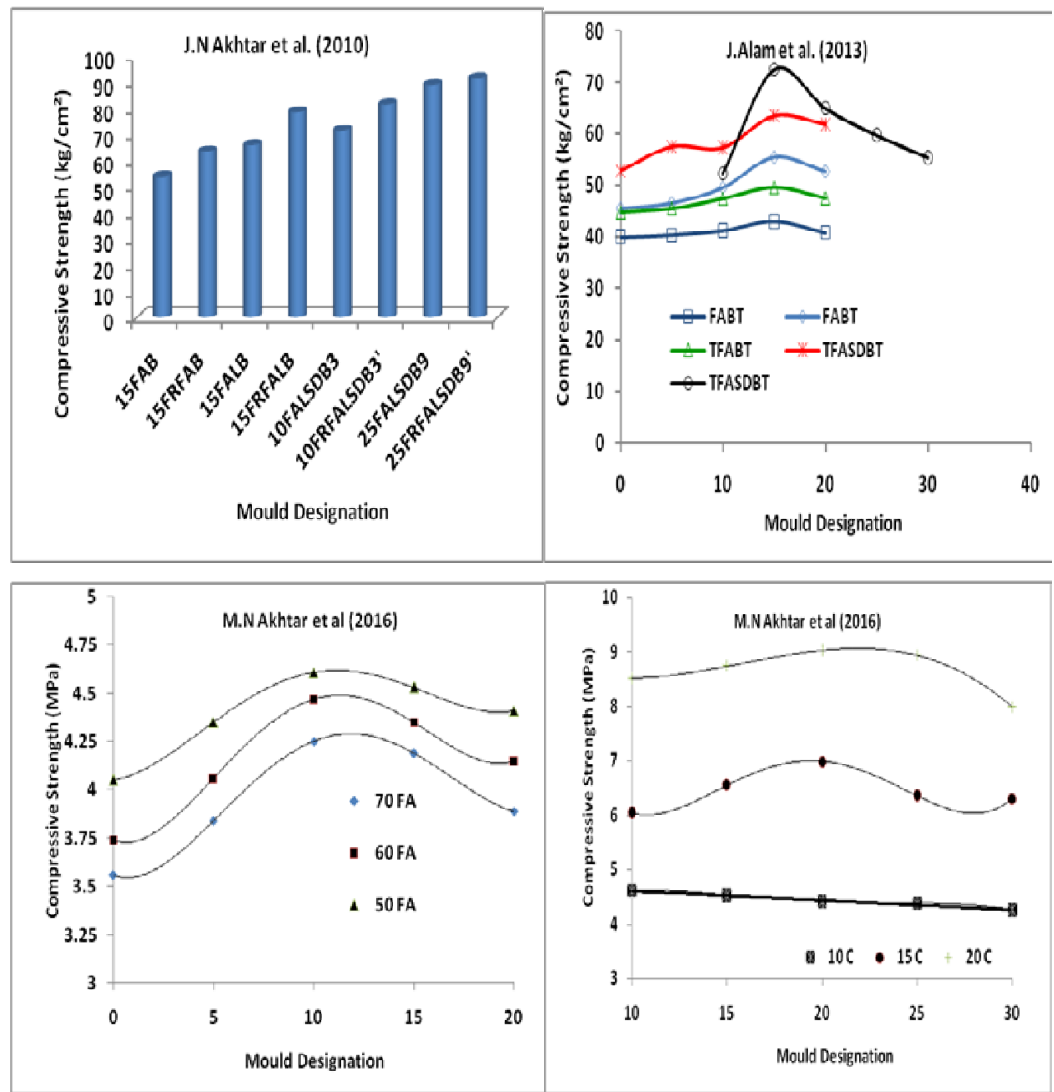

Fig. 7. (a),(b),(c), and (d) work of other researches with experimental curves obtained in several published studies. 


\section{Stress-strain behavior of fly ash based bricks and tiles}

The tests were performed in accordance with [9], and [10]. The stress-strain curves for the standard clay tiles obtained by averaging the stress strain data from ten samples of each type of clay tiles. The tiles were found to be behaving linearly up to about onethird of the ultimate failure load after that the behavior became highly nonlinear. An average stress-strain curve for all the tiles types used in the study is also shown in Figure. 8 [8]. The stress-strain curves for fly ash based tiles for six grades of mould obtained by averaging the data from ten specimens of each grade. Initial straight portion of the stress-strain curve (up to about one-third of mould strength) is followed by a nonlinear curve almost same as stress-strain curves for standard clay brick tiles (SCBT) discussed above which extends well beyond the strain limits corresponding to the tiles samples. Strain readings on the falling branch of the stress-strain curve could not be recorded for the very weak moulds because of its brittle and explosive crushing failure after reaching the ultimate strength. Figure. 9(a) shows that the stress-strain curve comparison for six different combination grades of moulds TFASDRT. Data points represent experimental results and solid lines represent corresponding trend lines. A comparison of stress-stain curves generated by the TFASDRT and SCBT obtained in the present experimental study is shown in Figure. 9(b), which show a very close match between the TFASDRT and SCBT curves [8]. The stress strain curves of different test series of FAB, FRFAB, FALB, FRFALB, FALSDB and FRFALSDB have been plotted and shown in Figure 10 [6]. Each stress-strain curve is the average of three bricks pair [6].

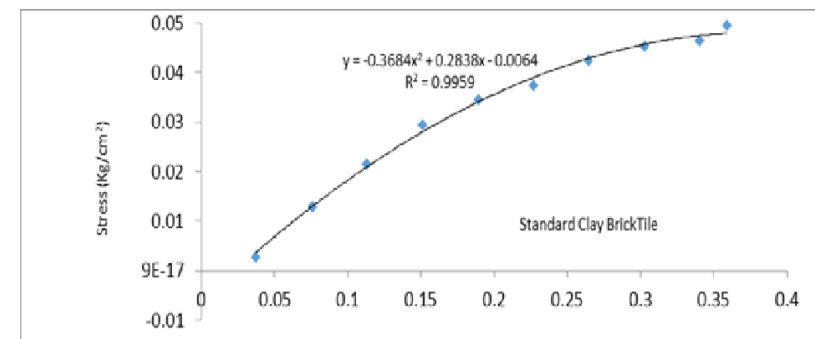

Strain

Fig. 8 Stress-strain curve behavior for standard clay brick tiles

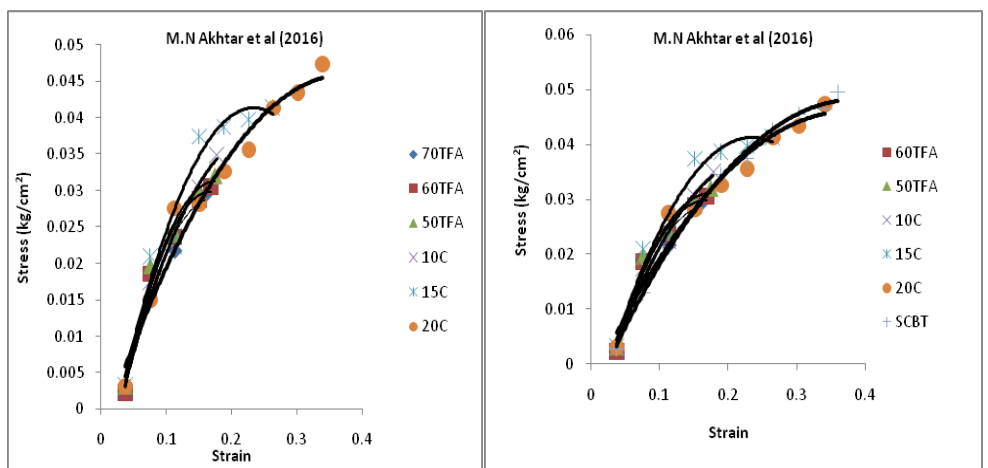

Fig. 9 (a,b). Stress-strain curve behavior of TFASDRT and Comparison of stress-strain curves of TFASDRT and SCBT. 


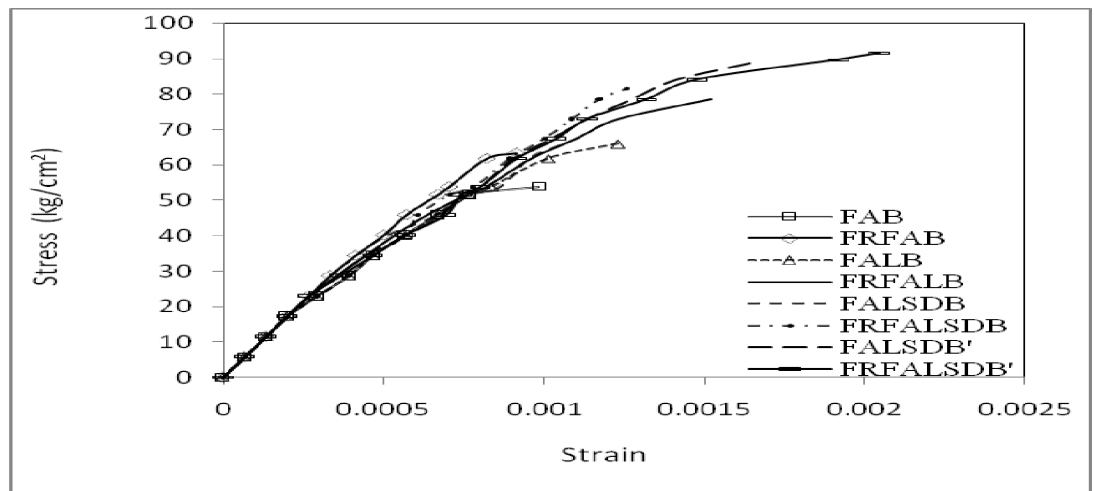

Fig. 10. Stress vs. Strain variation of fly ash based bricks.

\section{Benefits of fly ash based composite material with cement}

Cement is a binding material, which is widely used in construction industry. It is made from limestone, clay and various additives, such as powered gypsum and fly ash. Gypsum $\left(\mathrm{CaSO}_{4} \cdot 2 \mathrm{H}_{2} \mathrm{O}\right)$ is a common and soft mineral. It is used as a set retarder in the early stage of hydration. It keeps the mortar of the concrete in a plastic stage for longer time and therefore it prolongs concrete workability. The combination of T.F.A and R.S.D with cement discloses the various important benefits of the composite material. The replacement of cement by fly ash reduces water demand and the decreased water demand has a little or no effect on drying shrinkage/cracking. So, the reduction in free lime and the resulting increase in cementitious compounds combined with the reduction in permeability and enhance the mortar durability. The additional binder produced by the fly ash reaction with available lime allows fly ash based composite material to continue to gain strength over time. The failure modes of tested samples are shown in Figure 11. Weak mortar was found to be very weak and soft as compared to other three i.e., intermediate, strong and very strong. Intermediate mortar perform stable as compared to weak and strength increased about $(29.41 \%)$, then Strong mortar performed well in terms of strength and ductility as compared to other two, strong mortars was found $(51.40 \%)$, higher than intermediate mortar, in comparison of strong mortar very strong mortar was reached the highest strength about $(29.08 \%)$ more than the strong [8].
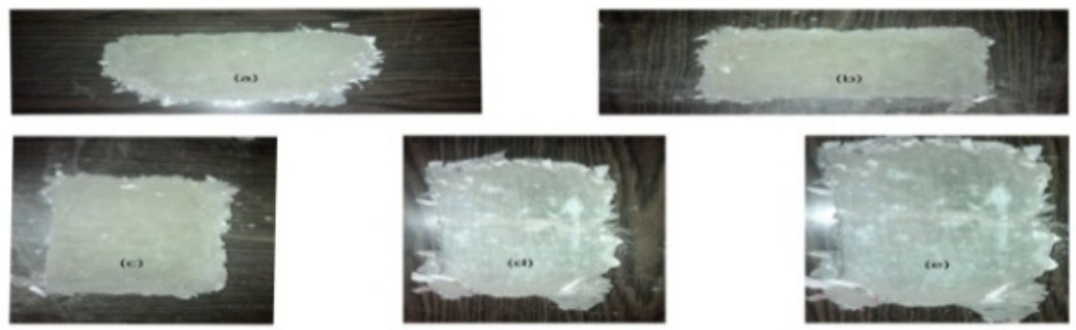

Fig. 11. Typical failure modes of: (a) Weak, 00TFASDRT (70\%TFA); (b) Intermediate, 10 TFASDRT (60\% TFA); (c) Intermediate, 10TFASDRT (50\%TFA); (d) Strong, 20TFASDRT $(15 \%$ C) (e) Very strong, 20TFASDRT $(20 \%$ C).

The spherical shaped particles of fly ash act as miniature ball bearings within the concrete mix,thus providing a lubricant effects. This same effect also improves concerete pumpability by reducing frictional lisses during the pumping process and flat work finish ability [11]. The replacement of cement by fly ash reduces the water demand for a given slump. When fly ash is used at about 20 percent of the total cementious, water demand is reduced by approximately 10 percent. Higher fly ash contents contain will yield higher water reductions. The decreased water demand has little or no effects on drying shriankage / cracking. Some fly ash is known to reduce drying shrinkage in certain situations [11]. Replacing cement with the same amount of fly ash can reduce the heat of hydration of concrete. This reduction in heat of 
hydration does not sacrifice long-term strength gain or durability. The reduced heat of hydration lessens heat rise problems in mass concrete placements [11]. The additional binder produced by the fly ash reaction with available lime allows fly ash concrete to continue to gain strength over time. Mixtures designed to produce equivalent strength at early ages (less than 90 days) will ultimately exceed the strength of straight cement concrete mixes [11].

\section{Control point defining the characteristics of the study}

Based on the past studies five control points were indentified, which correspond to the experimentally observed data and representing compressive behavior, stress-strain characteristics and safe utilization of fly ash as bricks and roof tiles in civil engineering construction industry.

The control points identified during the studies are as follows:

1.The chemical analysis identified that the waste materials are non-hazardous in nature.

2.The compressive strength of fly ash based bricks and tiles was found very closed to the standard strength of clay bricks and tiles.

3.The compressive strength [8], has been increased by $30.65 \%$ compared to the past study carried out by [7].

4.Addition of waste Polythene Fibre (W.P.F) provides more strength in the tiles as compared to the other past studies refer (Figure. 11 Typical failure modes).

5.Stress-strain curves have been generated by past experimental data and compared with the experimental curve obtained by standard clay brick and tile is fall almost on the same pattern.

\section{Conclusions}

Fly ash have become an important raw material for various industrial and construction applications. The objective of this paper was to investigate that the fly ash based bricks and roof tiles fits as construction materials and it can replace the conventional clay bricks and roof tiles. As shown, in the past studies the compressive behavior and stress-strain characteristics is almost as same as the standard clay bricks and roof tiles. The available tests mentioned in the past studies fouced only on the strength of the bricks and tiles and the strength based criteria is not enough to replace any building material in the construction industry. Design needs durability the construction materials fly ash based bricks and tiles must fulfill the acceptance criteria for durability tests. Measuring the durability factor of bricks and tiles to determine its longevity, and ability to withstand local weathering and use, is difficult to predetermine. Absorption and permeability test should be considered the main test to evaluate where bricks and tiles is subjected to such as basements, water reservoirs, building roofs, tunnels etc.In addition, the ample scope in the continuation of this study is for the investigation of the mechanical properties of the same samples.

\section{References}

[1] ASTM, "American Standards for Testing and Materials", Standard C618-05 "Standard specification for coal fly ash and raw or calcined natural pozzolan for use in concrete". (2005).

[2] ASTM, "American Standards for Testing and Materials". Standard C593-06 "Standard specification for fly ash and other pozzolans for use with lime for soil stabilization". (2006).

[3] X, Lingling, Guo Wei, Wang Tao and Yang Nanru Study on fired bricks with replacing clay by fly ash in high volume ratio Construction and Building Materials 19 (2005) 243-247.

[4] Y, Xue et al.,. Utilization of municipal solid waste incineration ash instone mastic asphalt mixture: Pavement performance and environmental impact. Construction and Building Materials Vol. 23, Issue 2, pp. 989-996 (2009)

[5] Charles Hoi King Lam et al.,. Utilization of municipal solid waste incineration ash in Portland cement clinker. Clean Technologies and Environmental Policy. Springer Vol. 13, Issue 4, pp. 607-615. (2011) 
[6] J.N Akhtar et al.. An Experimental study on fibre-reinforced fly ash based lime bricks. International Journal of physical Sciences Vol.5 (11), pp.1688-1695, ISSN 1992-1950 (2010)

[7] J. Alam et al. Flay ash Based Brick Tiles: An Experimental Study. International journal of emerging Trends in Engineering and development. Issue 3, Vol.6 ISSN 2249-6149 (2013).

[8] M.A Akhtar et al. Sustainable fly Ash Based Roof Tiles Waste Polythene Fibre: An Experimental Study. Open Journal of Civil Engineering, Vol- 6, Issue 2 pp.314-327 (2016). DOI: $10.4236 /$ ojce.2016.62026

[9] ASTM, "Standard test methods for sampling and testing brick and structural clay tile." Masonry test methods and specifications for the building industry, ASTMC67-00, 4th Ed., Philadelphia. (2001c).

[10] Indian Standards Indian standard methods of test of burn clay building bricksPart 1: Determination of compressive strength, IS 3495, 3rd Rev., Bureau of Indian Standards, New Delhi, India. (IS.1992a).

[11] Newsletter CBRI ENVIS Centre on fly ash (CBRI), Roorkee Vol.7 Issue(2) pp.18ISSN No.0974-2026. 